\title{
The Effect of Gender and School Climate on Job Satisfaction of Government Secondary School Teachers in Sidama Zone, Snnpr
}

\author{
Sintayehu Mebrate (MA)Solomon Lemma (PhD) \\ Assistant professor, school of education and training, Hawassa University
}

\begin{abstract}
The Study Investigated Effect Of Gender And School Climate On Job Satisfaction Of Teachers In Government Secondary Schools Of Sidama Zone. It Covered School Climate Facets That Affect Teacher Job Satisfaction: Working Environment, Work Itself, Relation With Co Workers, Pay, Opportunity For Promotion And Support From Supervisor. A Total Of 214 Teachers From Six (6) Secondary Schools Of Sidama Zone Were Randomly Selected For The Study. The Descriptive Survey Research Design Was Employed. Questionnaire Was Used As The Major Research Data Collection Instrument. Descriptive And Inferential Data Analysis Techniques Were Used For Data Analysis. Findings From The Study Revealed That The Major Facets Of School Climate With Which Teachers' Satisfied Were That: The Work Itself, Relation With Co Workers, And Support From Supervisor. On The Contrary, Teachers Were Dissatisfied With Pay And Opportunity For Promotion Facets. Furthermore, Teachers Were Neutral Towards Their Working Environment. In Addition, Correlation Analysis Revealed That Gender Difference Brings Difference On Job Satisfaction; Male Teachers Were Significantly More Satisfied Than Female Teachers. On The Other Hand, All The Six Facets Of School Climate Significantly Correlated With Job Satisfaction And Pay And Opportunity For Promotion Found That Affected Teachers' Job Satisfaction Highly. The Study Recommends That The Sidama Zone Education Department And Woreda Education Offices Have To Give Special Attention To Involvement And Satisfaction Of Female Teachers In Education Sector As well.
\end{abstract}

Key Words: Job Satisfaction, Gender, School Climate, Secondary school, teachers

\section{INTRODUCTION}

Attempts to improve performance in schools will never succeed if teachers' job satisfaction is ignored. If employees in an organization are motivated, they will render services to the employer and customers very efficiently and effectively (Mbua, 2003). This implies that motivated and satisfied teachers are most likely to affect the students learning positively while the opposite of that may have negative impacts on students' performance. Educational leaders and administrators/managers have to pay special attention to the phenomena of motivation and job satisfaction. According to Mwamwenda (in Badenhorst, George and Louw, 2008), a lack of teacher job satisfaction results in frequent teacher absenteeism from school, aggressive behaviour towards colleagues and learners, early exits from the profession, and psychological withdrawal from the work. All of these negative results lead to poor quality teaching. Other studies showed that a lack of job satisfaction is often accompanied by feelings of gloom, despair, anger, resentment and futility (Pinder, 2008). Thus, a lack of job satisfaction has serious implications for the teacher, as well as for the educational system in which he or she is employed. Dealing with employees' job satisfaction has important implications for the employees themselves and for their organisations. A satisfied teaching force leads to higher commitment and productivity because of fewer disruptions, such as absenteeism, the departure of 'good' employees, and incidences of destructive behaviour (Robbins, in Green, 2000). Gender, which is also one of the demographic variables, is the concern of this current study, has been extensively and globally investigated as both social and biological variable in the studies of job satisfaction. Whether gender affects job satisfaction or not, is one of the talked about issues in recent organizational behaviour literature (Goh, Koh \& Low, 1991). According to Mason (1997), "the question whether or not gender differences in job satisfaction exist has been answered both affirmatively and negatively in the literature" P 28. The research conducted among Canadian teachers revealed that job satisfaction levels differ significantly between male and female teachers (Ma \& MacMillan, 2001). Similar, study conducted in the United States revealed that there were significant differences in the levels of job satisfaction between male and female teachers (Bishay, 1996). They say that female teachers were more satisfied with their job than male teachers. Whereas, Zhongshan (2007) found that elementary school male teachers in Shanghai, China were more satisfied with their salaries than their female colleagues. Conversely, Crossman and Harris (2006) conducted a study on job satisfaction among secondary school teachers in United Kingdom and their findings indicated that their satisfaction levels did not differ significantly by gender. Even 
though, the effect of gender and school climate on job satisfaction was exhaustively done in the west, little was known in Ethiopia and the study area. Thus, this research tried to assess the effect of gender and school climate on government secondary school teachers' job satisfaction. Based on the background mentioned this study tied to met the following objectives.

- To identify whether gender difference leads to difference in job satisfaction among government secondary school teachers.

- To determine the correlation between the school climate variables such as working environment, work itself, relationship with co workers, pay, opportunity for promotion, supervision and job satisfaction of government secondary school teachers.

- To identify the school climate variables that highly affects job satisfaction of teachers in government secondary schools.

\section{Literature review}

\subsection{The Relationship between School climate and Job Satisfaction}

There has been huge amount of studies on the relationship between organizational climate and job satisfaction. Fisher (1985) for example has studied a group of new nurses, whom have just served for six months, to examine the relationship between social support and their job satisfaction. The first questionnaire was administered before they work. And the second questionnaire was administered after they started working. Social support was measured by focusing on the emotional support by colleagues and informational support from superiors. The result indicated positive, significant relationship between the two factors. Hence, it supported previous literatures that have proposed the importance of social support from colleagues as well as superiors on job satisfaction of new employees. A more recent study by Cohrs, Abele \& Dette (2006) on the relationship between organizational climate and job satisfaction was conducted on 1,065 German employees from three different professional groups. The examined organizational climate dimensions studied were social support, autonomy, promotion opportunity and leadership. Correlation analysis resulted in positive and significant relationship between employees' perceptions towards leadership and job satisfaction level for all the three samples. For the second and third sample, it was found that there were more positive perception towards social support, autonomy and promotion. This thus contributed to higher level of job satisfaction.Another study by Schulte, Ostroff and Kinicki (2006) involved 1,076 employees from 120 bank branches in the United States of America. The objective of the study was to examine the influence that individual's climate and work climate perceptions have on job satisfaction. Job satisfaction was measured using 'Minnesota Satisfaction Questionnaire'. Among the dimensions were satisfaction towards supervision, colleagues, rewards, work activities, workloads, promotion opportunities, job security, physical environment and interactions with clients. The above discussion exhibited that most of the past studies have reported solid relationships between organizational climate and job satisfaction. Meanwhile, social and relationship turned out to be the most popular and significant organizational climate dimension in explaining employees' job satisfaction.

\subsection{The Relationship between Gender and Job Satisfaction}

In studies on job satisfaction, gender is a frequently investigated variable. The investigation of this variable as a determinant of job satisfaction is a sensitive issue. This is because there is a substantial increase in the number of women joining the labour force in recent times (Castel, Bernal, Navaro \& Torres, 2005; Oshagbemi, 2000), and this has generated considerable interest for the need to investigate the influence of gender on job satisfaction. Although the relationship between gender and job satisfaction has been investigated extensively, the results of many of the studies so far have been found inconsistent, contradictory and far from unanimous. Where some studies found women more satisfied with their work, others indicated that the men were more content (Crossman \& Harris, 2006; Ma \& McMillan, 1999).Numerous studies in different parts of the world have shown women to be more satisfied with the teaching profession than men (Akhtar \& Ali, 2009; Bogler, 2005; Jyoti \& Sharma, 2006; Kim, 2005; Koustelios, 2001; Ladebo, 2005). Kim (2005) observed that in the Seoul Metropolitan Government studies of gender differences in Korea, the women reported more satisfaction with their jobs than the men, and the credible reasons are that women place greater value than men on intrinsic rewards. In a similar study Koustelios (2001) found that the women teachers were more satisfied with their working conditions than the men, because women employees tend to consider the working conditions to be more favourable than the men do. The following figure was used as a conceptual framework of the study 


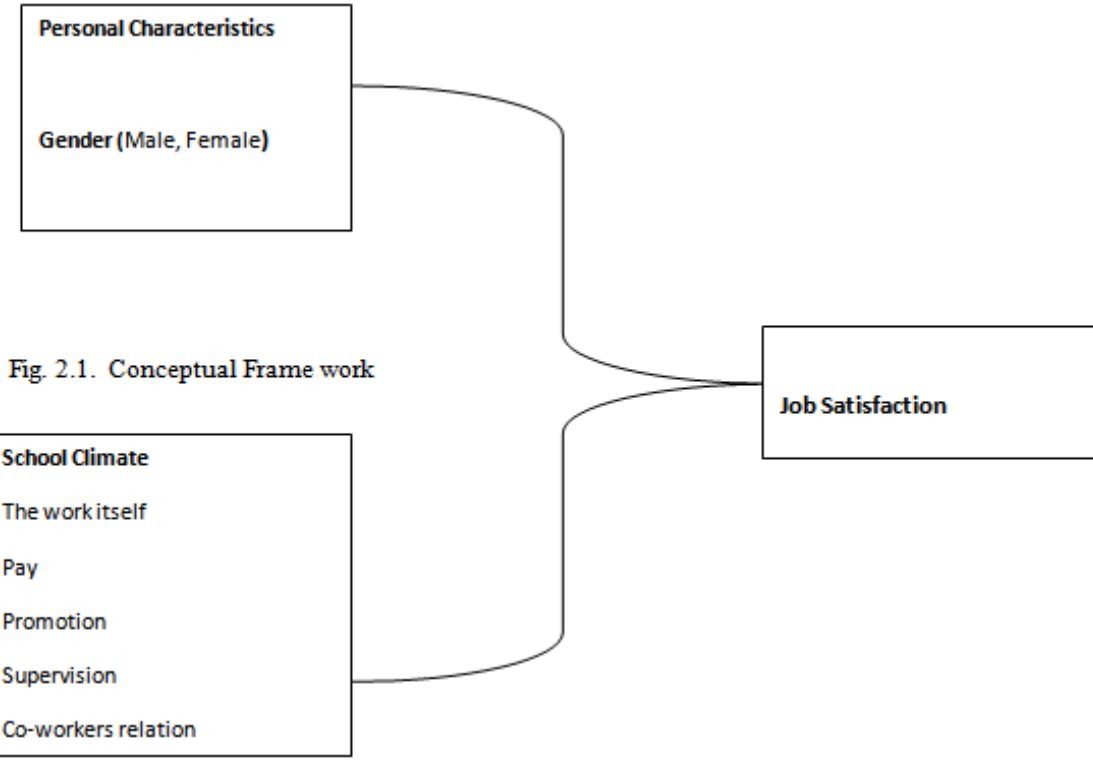

\section{METHODOLOGY}

Descriptive survey design was used. To determine the sample size for teachers Yamane's (1967) formula was used. Using the formula 220 teachers was selected by simple random sampling technique. In addition, to minimize gender imbalance all female teachers were taken from the sampled schools. Questionnaire and interviews were used as data collection tools. The questionnaire is segmented in to two parts: Part A contains the general information of the respondents addressing the demographic characteristics such as gender, qualification and teaching experience. Part B contains the job satisfaction facets/ dimensions. The job satisfaction was measured with the construction of the five point Likert scales which identify the different level o job satisfaction. Descriptive and inferential statistics was used to analyse quantitative data.

\section{DISCUSSION AND PRESENTATION OF DATA}

\subsection{Characteristics of the respondents}

The quantitative result revealed that the gender composition of 214 sampled teachers consisted of $70.1 \%$ males and $29.9 \%$ females. This illustrates that female academic staff is very limited in secondary schools of the zone. With respect to the academic status, the majority of the teachers, roughly $81.3 \%$ were first degree holders, $16.4 \%$ were diploma holders and $2.3 \%$ were Master degree holders. These findings verify that most of the teachers in Sidama zone meet the standard set by Ministry of Education (MoE 2011). The majority of the sampled teachers $(43 \%)$ had less than five (5) years experience. Only 30.8\% had between 6 to 10 years experience and the remaining $26.2 \%$ had more than ten (10) years teaching experience.

\subsection{Job satisfaction of Secondary school teachers towards six dimensions of school climate}

Based on dimensions of school climate, the level of satisfaction of government secondary school teachers of Sidama zone towards working environment, work itself, opportunity for promotion, relation with co workers, pay and support from supervisors were measured by developing questionnaire for each dimension of school climate.

Table 1. Level of Satisfaction of public Secondary School teachers of Sidama Zone towards school climate dimensions

\begin{tabular}{|l|l|l|l|l|}
\hline No & School climate dimensions & Mean & S.D & Meaning \\
& & & & \\
\hline 1 & Working Environment & 3.13 & 0.88 & Neutral \\
\hline 2 & Work itself. & 3.412 & 0.84 & Satisfied \\
\hline 3 & Relation with co workers & 3.65 & 0.58 & Satisfied \\
\hline 4 & Pay & 2.12 & 0.83 & dissatisfied \\
\hline
\end{tabular}




\begin{tabular}{|l|l|l|l|l|}
\hline 5 & Opportunity for promotion & 2.54 & 0.87 & dissatisfied \\
\hline 6 & Support from supervisors & 3.43 & 0.78 & Satisfied \\
\hline
\end{tabular}

Note: $1.00-1.80=$ very unsatisfied, $1.81-2.60=$ unsatisfied, $2.61-3.40=$ not sure, $3.41-4.20=$ Satisfied, $4.21-5.00=$ very satisfied

The results on Table 1 indicate that teachers are neutral towards their working environment. On the other hand they are satisfied with the nature of the work, relation with co workers and support from supervisors. In addition teachers of government secondary schools of Sidama zone are dissatisfied with pay and opportunity for promotion dimensions. Here the result of interview of some teachers indicates that the pay they get do not balanced with their contribution and does not fulfil their basic needs. Regarding opportunity for promotion there is no fair competition to be promoted, instead of academic achievement and competency, political involvement and other subjective issues used as criteria for promotion as the interview result revealed.

Table 2. Frequency and Percentage on overall job satisfaction of government secondary school teaches

\begin{tabular}{|l|l|l|l|}
\hline & Frequency & Percent & Valid Percent \\
\hline Dissatisfied & 147 & 68.7 & 68.7 \\
\hline Satisfied & 67 & 31.3 & 31.3 \\
\hline Total & 214 & 100 & 100 \\
\hline
\end{tabular}

The descriptive analysis on overall job satisfaction shows that $68.7 \%$ of the teachers are not satisfied with their working in their respective schools. On the other hand, $31.3 \%$ of the teachers are satisfied with their work. The result of descriptive analysis on the overall job satisfaction of teachers implied that most of the teachers are dissatisfied with their work.

\subsection{Analysis of correlation of Gender with Job satisfaction}

The first objective of the research is to identify whether there is significance relation between gender difference and job satisfaction. To sort out this objective analysis conducted by using Independent sample t-test and the study found that the means of male and females are significantly. Since Levene's Test for Equality of Variance is significant, $\mathrm{P}<0.05$, equal variance not assumed and the results of the bottom row was taken. From the Group Statistics table it is possible to see that male teachers were slightly more satisfied than female teachers on their job. The analysis also revealed a statistically significant

Table 4. Results of analysis of correlation of Gender with Job satisfaction

\section{Independent Samples Test}

OJS: overall Job Satisfaction

\begin{tabular}{|c|c|c|c|c|c|c|c|c|c|c|}
\hline & \multicolumn{2}{|c|}{$\begin{array}{l}\text { Levee's Test for } \\
\text { Equality of } \\
\text { Variances }\end{array}$} & \multicolumn{7}{|c|}{ t-test for Equality of Means } \\
\hline & & \multirow[t]{2}{*}{$\mathrm{F}$} & \multirow[t]{2}{*}{ Sig. } & \multirow[t]{2}{*}{$\mathrm{t}$} & \multirow[t]{2}{*}{ df } & \multirow{2}{*}{$\begin{array}{l}\text { Sig. } \\
(2- \\
\text { tailed } \\
)\end{array}$} & \multirow[t]{2}{*}{$\begin{array}{l}\text { Mean } \\
\text { Differ } \\
\text { ence }\end{array}$} & \multirow{2}{*}{$\begin{array}{l}\text { Std. } \\
\text { Error } \\
\text { Differ } \\
\text { ence }\end{array}$} & \multicolumn{2}{|c|}{$\begin{array}{l}95 \% \text { Confidence } \\
\text { Interval of the } \\
\text { Difference }\end{array}$} \\
\hline & & & & & & & & & Lower & Upper \\
\hline \multirow{2}{*}{ OJS } & $\begin{array}{l}\text { Equal } \\
\text { variances } \\
\text { assumed }\end{array}$ & 51.712 & .000 & 2.955 & 212 & .003 & .201 & .068 & .067 & .336 \\
\hline & $\begin{array}{l}\text { Equal } \\
\text { variances not } \\
\text { assumed }\end{array}$ & & & 3.255 & 150.303 & .001 & .201 & .062 & .079 & .324 \\
\hline
\end{tabular}

finding in line with the findings of Chiu (1998) and Lyness and Thompson (1997), all report that men are more satisfied than women in their work-

4.4 Analysis of correlation of facets of school climate with job satisfaction

Table 5. Correlation of School climate facets with Job Satisfaction 
The correlation of independent variables (WC, WI, RC, P, OP, SS) with dependent variable (Job Satisfaction)

On the other hand, all the school climate variables significantly correlated with overall job satisfaction as described below:

1. Correlation of Working Environment with Job Satisfaction

The analysis shows that working environment is strongly correlated with overall job satisfaction with the result of $(\mathrm{r}=.548)$. This implies that improving the working condition will improve the job satisfaction of teachers. On a similar study Rasku and Kinnunen (2003), found that Finnish secondary school teachers expressed more job satisfaction than their counterparts in other European countries in which the study was conducted. Their satisfaction was a result of the fact that they are assured their wellbeing through working.

2. Correlation of Work itself with Job Satisfaction

\begin{tabular}{|c|c|c|c|c|c|c|c|c|}
\hline & & $\mathrm{WE}$ & WI & $\mathrm{RC}$ & $\mathrm{P}$ & OP & SS & OJS \\
\hline \multirow[t]{3}{*}{ WE } & Pearson Correlation & 1 & .405 & $\begin{array}{l}.38 \\
7^{* *}\end{array}$ & .515 & $\begin{array}{l}.40 \\
3^{* * *}\end{array}$ & .376 & $.548^{*}$ \\
\hline & Sig. (2-tailed) & & .000 & $\begin{array}{l}.00 \\
0\end{array}$ & .000 & $\begin{array}{l}.00 \\
0\end{array}$ & .000 & .000 \\
\hline & $\mathrm{N}$ & & 214 & 214 & 214 & 214 & 214 & 214 \\
\hline \multirow[t]{3}{*}{ WI } & Pearson Correlation & & 1 & $6^{* *}$ & .416 & .35 & $\begin{array}{l}312 \\
* * *\end{array}$ & $.580^{*}$ \\
\hline & Sig. (2-tailed) & & & $\begin{array}{l}.00 \\
0\end{array}$ & .000 & $\begin{array}{l}.00 \\
0\end{array}$ & .000 & .000 \\
\hline & $\mathrm{N}$ & & & 214 & 214 & 214 & 214 & 214 \\
\hline \multirow[t]{3}{*}{$\mathrm{RC}$} & Pearson Correlation & & & 1 & .236 & $\begin{array}{l}.25 \\
9^{* *}\end{array}$ & .500 & $.488^{*}$ \\
\hline & Sig. (2-tailed) & & & & .000 & $\begin{array}{l}.00 \\
0\end{array}$ & .000 & .000 \\
\hline & $\mathrm{N}$ & & & & 214 & 214 & 214 & 214 \\
\hline \multirow[t]{3}{*}{$\mathrm{P}$} & Pearson Correlation & & & & 1 & .62 & .362 & $.678^{*}$ \\
\hline & Sig. (2-tailed) & & & & & $\begin{array}{l}.00 \\
0 \\
\end{array}$ & .000 & .000 \\
\hline & $\mathrm{N}$ & & & & & 214 & 214 & 214 \\
\hline \multirow[t]{3}{*}{ OP } & Pearson Correlation & & & & & 1 & .464 & $.594^{*}$ \\
\hline & Sig. (2-tailed) & & & & & & .000 & .000 \\
\hline & $\mathrm{N}$ & & & & & & 214 & 214 \\
\hline \multirow[t]{3}{*}{ SS } & Pearson Correlation & & & & & & 1 & $.512^{*}$ \\
\hline & Sig. (2-tailed) & & & & & & & .000 \\
\hline & $\mathrm{N}$ & & & & & & & 214 \\
\hline \multirow[t]{3}{*}{ OJS } & Pearson Correlation & & & & & & & 1 \\
\hline & Sig. (2-tailed) & & & & & & & \\
\hline & $\mathrm{N}$ & & & & & & & \\
\hline \multicolumn{9}{|c|}{$\begin{array}{l}\text { **. Correlation is significant at the } 0.01 \text { level (2-tailed). } \\
\text { Note: WE: working Environment, WI: Work Itself, RC: Relation with Co workers, P: Pay, } \\
\text { OP: Opportunity for Promotion, SS: Support from Supervisor and OJS: Overall Job } \\
\text { satisfaction }\end{array}$} \\
\hline
\end{tabular}

The result of the analysis implies that the work itself strongly correlated with overall job satisfaction ( $\mathrm{r}$ $=.580)$. The result implies that the work itself affects job satisfaction strongly and improving the work itself leads to improvement in job satisfaction. According to Kim (2005), individuals who score high in the intrinsic aspects of the work related to the work itself, have high possibilities of reporting satisfaction. Intrinsicallymotivated individuals give high values to the work itself, to feelings of self-determination, and to competence and personal development. 


\section{Correlation of $\mathrm{Co}$ - workers with Job Satisfaction}

The result indicates that relation with co workers moderately correlated with overall job satisfaction $(r=.488)$. This implies that relation with co workers affect overall job satisfaction moderately. This finding has supported by the previous finding on correlation of relation with co workers with job satisfaction. For example, Mowday \& Sutton, (1993), suggests that job satisfaction is related to employees' opportunities for interaction with others on the job. Studies have shown that the better relationship, the greater the level of job satisfaction (Wharton \& Baron, 1991). The importance of good relations with colleagues for job satisfaction is well-documented, and confirmed by numerous studies in different cultures. Bogler (2005) found that both Arab and Israeli teachers viewed their relations with teachers and colleagues as some of the most satisfying characteristics of their job. He concluded that relationships with colleagues contributed significantly to the teachers' satisfaction

\section{Correlation of Pay with Job Satisfaction}

Strong correlation was observed between pay and overall job $(\mathrm{r}=.678)$. This implies that pay strongly affecting job satisfaction, in other words improving pay improve job satisfaction secondary school teachers strongly. A considerable number of research reports have reported that the teachers' job satisfaction was related positively to the teachers' salaries (Gates \& Mtika, 2011; Ingersoll \& Smith, 2003; Liu \& Meyer, 2005). According to these studies, an increase in salary was followed by a considerable raise in the teachers' job satisfaction. Chang, Kim, and Tickle (2010) also demonstrated that the teachers' satisfaction with their salaries was a significant predictor of their job satisfaction. Therefore, the finding of this research on the correlation of pay with job satisfaction has supported by other finding as mentioned above.

\section{Correlation of opportunity for Promotion with Job Satisfaction}

Promotion opportunity also strongly correlated with overall job satisfaction $(\mathrm{r}=.594)$. This implies promotion opportunity strongly affect overall job satisfaction of secondary school teachers. This finding is in line as shown by Choi and Tang (2009), teachers said that the availability of opportunities for career advancement and recognition of their contribution to schools improved their teaching efforts. Teachers are more satisfied if their jobs provide opportunities for personal and professional advancement (Rosenholtz, in Sargent \& Hannum, 2005).According to the Expectancy Theory, promotion is a visible reward that comes as a result of the employees' effort and performance. If the teachers are promoted to a level higher than their present position as a result of their increased efforts, they are rewarded for their efforts (Ellickson, 2002). Ellickson (2002) also believes that opportunities for promotion are important determinants of employee job satisfaction. Since the finding of this research also showed that there was strong correlation between promotion opportunity and job satisfaction, it support the findings mentioned above.

\section{Correlation of Support from supervisors with Job Satisfaction}

The result of the analysis implies that support from supervisor strongly correlated with overall job satisfaction ( $\mathrm{r}$ $=.512$ ). This implies that support of supervisor affects job satisfaction strongly. Research appears to be vague since most research indicates that individuals are likely high levels of job satisfaction, if supervisors provide them with support and corporation in completing their tasks (Ting, 1997). Tekleselassie (2005) argues that the teachers' willingness to participate in all areas of decision-making will come to the force, if they perceive their relationships with their principals as being open, collaborative, facilitative, and supportive. In addition, supportive principals will also determine the teachers' rate of attrition. It can therefore be concluded that teachers will be successful, motivated, and inspired to do their best if there exists a healthy relationship between them and the school principals (Edgerson \& Kritsonis, 2006). In general, Job satisfaction strongly correlated with Working condition $(\mathrm{r}=.548)$, work itself $(\mathrm{r}=.580)$, pay $(\mathrm{r}=.678)$, opportunity for promotion $(\mathrm{r}=.594)$ and support from supervisor $(\mathrm{r}=512)$ and moderately correlated with relation with co workers $(\mathrm{r}=.488)$. From the analysis of correlation the study found that job satisfaction has highest correlation with pay $(\mathrm{r}=.678)$ and least correlation with relation with co workers $(\mathrm{r}=.488)$. This means job satisfaction of secondary school teachers less affected by relation with co workers as compared with other dimensions.

\section{CONCLUSIONS AND RECOMMENDATIONS}

This study has found that out of six facets of school climate, public secondary school teachers in Sidama Zone are mostly satisfied with the intrinsic factors like nature of work, relation with co workers and Supervision. On The Other Hand, Secondary School Teachers Are Unsatisfied With Extrinsic Factors Such As Pay, Fringe Benefits And Opportunity For Promotion. In Line With This Research Finding Previous Study Conducted On Teacher Motivation In Tanzania Revealed That Teachers Were Not Happy With Pay And Fringe Benefits (Davidson, 2007). On The Contrary, Government Secondary School Teachers Are Neutral Towards Their Working Environment. This Was Due To Absence Of Entertainment Area, Noisy Working Place, Etc The Factors Made Them Uncomfortable. In Addition, Since Working Environment Is Multi Dimensional Factor 
Secondary School Teachers were not understood it very well. They were happy with some of the elements of working environment and uncomfortable with some of them. Regarding the effects of gender on job satisfaction the result indicated that teachers' job satisfaction differed significantly in relation to gender. In which male teachers are more satisfied than female teachers. This implies that mostly male teachers retain in education sector than female teachers and which is affecting female participation in education sector. The study also revealed that job satisfaction strongly correlated with working environment, work itself, pay, opportunity for promotion and support from supervision and moderately correlated with relation with co workers. The finding implies that school climate dimensions (working environment, work itself, relation with co workers, pay opportunity for promotion and supervision) affects job satisfaction of public secondary school teachers. Even if, all of the school climate dimensions affect job satisfaction of government secondary school teachers, pay and opportunity for promotion are highly affecting job satisfaction of secondary school teachers in Sidama Zone. Therefore Ethiopian government and Sidama zone education office and policy makers have to work towards improving teachers' pay, benefits and designing criteria for promotion. Even though the teachers of government secondary schools in Sidama Zone are satisfied with some of the school climate dimensions, the overall job satisfaction analysis has revealed that most of the teachers are unsatisfied. Since job satisfaction is the core element in promoting quality education, the government as well as Sidama Zone education experts and policy makers have to device means of boosting teacher's job satisfaction like improving working environment, fair promotion opportunity, benefits and salary. The study also recommends that Sidama Zone education bureau and woreda education offices should have a scheme which will enhance fairness in the promotion of teachers and where the teachers will have equal chances of promotion. On top of that it was recommended that Sidama Zone education department has to design strategy towards improving female teachers' participation and satisfaction.

[1] Akhtar, Z. \& Ali, N. (2009) . Job status, gender and level of education as determinants of job satisfaction of senior secondary school teachers. Indian: Journal of Social Science Researches, 6(1):5659 .

[2] Badenhorst, G., George, E. \& Louw, D. (2008). Job satisfaction among urban secondary school teachers in Namibia. South African : Journal of Education, 28:135-154.

[3] Bishay, A. (1996). Teacher motivation and job satisfaction: a study employing the experience sampling method. Journal of Undergraduate Sciences, 3, 147-154.

[4] Bogler, R. (2005). The satisfaction of Jewish and Arab teachers in Israel. Journal of Social Psychology, 145(1):19-33.

[5] Chang, M., Kim, S. \& Tickle, B.R. (2010). Administrative support and its mediating effect on US public school teachers. Teaching and Teacher Education, 30:1-8.

[6] Chiu, C. 1998. Do professional women have lower job satisfaction than professional men? Lawyers as a case study. Sex Roles, 38(7/8):521-537.

[7] Choi, P.L. \& Tang, S. (2009). Teacher commitment trends: cases of Hong Kong teachers from 1997 to 2007. Teaching and Teacher Education, 25(5):767-777.

[8] Cohrs, J.C., Abele, A.E. \& Dette, D.E. (2006). Integrating situational and dispositional determinants of job satisfaction: Findings from three samples of professionals. The Journal of Psychology: Interdisciplinary and Applied 140 (4), 363-395.

[9] Crossman, A. \& Harris, P. (2006). Job satisfaction of secondary school teachers. Educational Management Administration and Leadership, 34(1):29-46.

[10] Davidson, E. (2007). The Pivotal Role of Teacher Motivation in Tanzania. The Educational Forum, 157-166.

[11] Edgerson, D.E. \& Kritsonis, W.A. (2006). Analysis of the influence of principal-teacher relationships on student academic achievement: a national focus. Doctoral Forum: National Journal for Publishing and Mentoring Doctoral Student Research, 1(1):1-5.

[12] Ellickson, M.C. (2002). Determinants of job satisfaction of municipal government employees. Personnel Management, 31(3):343-358.

[13] Fisher, C. (1985). Social support and adjustment to work: A longitudinal study. Journal of Management. 11, 39-53.

[14] Gates, P. \& Mtika, P. (2011). What do secondary trainee teachers say about teaching as a profession of their 'choice' in Malawi? Teaching and Teacher Education, 27:424-433.

[15] Goh, C.T., Koh, H.C. and Low, C.K. (1991). Gender effects on the job satisfaction of accountants in Singapore. Work and Stress,5(4), 341-8.

[16] Green, J. (2000). A study of job satisfaction of community college chairpersons. Unpublished doctoral thesis. Blacksburg, VA: Virginia Poly technique Institute and State University 
[17] Ingersoll, R.M. \& Smith, T.M. (2003). The wrong solution to teacher shortage. Educational Leadership, 60(8):30-34.

[18] Jyoti, J. \& Sharma, R.D.( 2006). Job satisfaction among school teachers. IIMB Management Review, 18(4):349-363.

[19] Kim, S. (2005). Gender differences in job satisfaction of public employees: a study of Seoul Metropolitan government, Korea. Sex Roles, 52(9/10):667-681.

[20] Koustelios, AD. (2001). Personal characteristics and job satisfaction of Greek teachers. The International Journal of Educational Management, 15(7):354-358

[21] Liu, X.S. \& Meyer, J.P. (2005). Teachers' perceptions of their jobs: a multi-level analysis of the teacher follow-up survey for 1994-95. Teacher College Record, 107(5):985-1003

[22] Locke, E.A. (1976). The nature and causes of job satisfaction. Dlm Dunnette (pnyt.). Handbook of industrial and organizational Psychology, 1297-1349. Chicago: Rand McNally

[23] Lyness,K.S., \& Thompson,D.E. (1997). Above the glass ceiling? A comparison of matched sample of female and male executives. Journal of Applied Psychology, 82, 359-375

[24] Ma, X. \& MacMillan, R. (2001). Influences of work place conditions on teachers ${ }^{\text {ee }}$ job satisfaction. The Journal of Educational Research, 93, No. 1, 39-47.

[25] Ma, X. \& McMillan, R. (1999). Influences of workplace conditions on teachers' job satisfaction. Journal of Educational Research, 93(1):39-47.

[26] Mbua, F. N. (2003). Educational Administration: Theory and Practice. Limbe, South West Province, Cameroon: Design House.

[27] Mowday, R and R. Sutton. (1993).Organizational behavior: Linking individuals and groups to organizational context . Annual Review of Psychology.44p

[28] Mugenda, O.M. and Mugenda, A.G. (1999). Research Methods: Quantitative and Qualitative

[29] Oshagbemi,T. (2000). How satisfied are academics with their primary tasks of teaching, research and administration and management. International Journal of Sustainability in Higher Education 1(2), 124136.

[30] Pinder, C.C.( 2008). Work motivation in organizational behaviour. (2nd ed.). New York: Psychology Press

[31] Rasku , A., \& Kinnunen, U. (2003). Job Conditions and Wellness among Finnish Upper Secondary School Teachers. Psychology and Health, 18 No. 4, 441-456.

[32] Schulte, M., Ostroff, C. \& Kinicki, A.J. (2006). Organizational climate systems and psychological climate perceptions: A cross-level study of climate. Journal of Occupational and Organizational Psychology 79, 645-671.

[33] Tekleselassie, A.A.( 2005). Teachers' career ladder policy in Ethiopia: an opportunity for professional growth or 'a stick disguised as a carrot'? International Journal of Educational Development, 25:618636

[34] Ting, Y. (1997). Determinants of job satisfaction of federal government employees. Public Personnel Management, 26(3), 313-334

[35] Wharton,A.,\& Baron,J.(1991). Satisfaction? The psychological impact of gender segregation on women at work. Sociological Quarterly.

[36] Yamane, T. (1967). Statistics: an introductory analysis, $2^{\text {nd }}$ ed. New York: Harper and Row.

[37] Zhongshan, Z. (2007). Study of job satisfaction among elementary schools in Shanghai. Chinese Educational Society, Vol. 40, No. 5, 40-46. 